\title{
Leukocyte Antigen CD37
}

National Cancer Institute

\section{Source}

National Cancer Institute. Leukocyte Antigen CD37. NCI Thesaurus. Code C102769.

Leukocyte antigen CD37 (281 aa, $32 \mathrm{kDa}$ ) is encoded by the human CD37 gene. This protein is involved in the regulation of humoral immunity. 